\title{
Shock Therapy in Danish Psychiatry
}

\author{
JESPER VACZY KRAGH*
}

In the last decade, a new history of shock therapy in psychiatry has emerged. Electroshock or electroconvulsive therapy (ECT) in particular has attracted the attention of the scholars German Berrios, Roberta Passioni and Max Fink, who have each examined the scientific origins of the therapy. ${ }^{1}$ Timothy W Kneeland and Carol A B Warren have explored its history in the United States, and Jonathan Sadowsky has analysed its reception by American psychoanalysts in the twentieth century. ${ }^{2}$ Most recently, the extensive monograph Shock therapy by Edward Shorter and David Healy has provided new insights into the invention of ECT in Italy and its use in the United States and in several other countries. ${ }^{3}$ Specialized studies of the portrayal of ECT in films, popular magazines, and of patient consent to the therapy in Britain have also been published. ${ }^{4}$ The former image of ECT as a brutal and brain-disabling treatment has been challenged by this new literature. Instead, the recent studies have focused on the life-saving results of shock therapy and its positive effect on depression, characterizing ECT as the "penicillin of psychiatry". 5

The contemporary rise of electroconvulsive therapy has undoubtedly influenced its historiography. ECT is thus undergoing a comeback, and the historical literature on the treatment has been accompanied by a series of books advocating its benefits in psychiatry today. ${ }^{6}$ However, criticism of shock therapy has not ceased, and unfavourable studies of

(C) Jesper Vaczy Kragh 2010

* Jesper Vaczy Kragh, PhD, Medical Museion, Institute of Public Health, University of Copenhagen, Fredericiagade 18, DK-1310 Copenhagen K, Denmark; e-mail: jkvy@sund.ku.dk

\footnotetext{
${ }^{1}$ German E Berrios, 'The scientific origins of electroconvulsive therapy: a conceptual history', Hist. Psychiatry, 1997, 8: 105-19; Roberta Passione, 'Italian psychiatry in an international context: Ugo Cerletti and the case of electroshock', Hist. Psychiatry, 2004, 15: 83-104; Max Fink,

Electroshock: healing mental illness, 2nd ed., Oxford University Press, 2002.

2 Timothy W Kneeland and Carol A B Warren, Pushbutton psychiatry: a history of electroshock in America, Westport, Praeger, 2002; Jonathan Sadowsky, 'Beyond the metaphor of the pendulum: electroconvulsive therapy, psychoanalysis and the styles of American psychiatry', J. Hist. Med. Allied Sci., 2006, 61 (1): 1-25. See also Zigmond M Lebensohn, 'The history of electroconvulsive therapy in the United States and its place in American psychiatry: a personal memoir', Compr. Psychiatry, 1999, 40: 170-81.

${ }^{3}$ Edward Shorter and David Healy, Shock therapy: a history of electroconvulsive treatment in mental
}

illness, New Brunswick, Rutgers University Press, 2008.

${ }^{4}$ Andrew McDonald and Garry Walter, 'The portrayal of ECT in American movies', J. ECT, 2001, 17: 264-74; Laura Hirshbein and Sharmalie Sarvananda, 'History, power, and electricity: American popular magazine accounts of electroconvulsive therapy, 1940-2005', J. Hist. Behav. Sci., 2008, 44: 1-18; Claire Hilton, 'Changes between the 1959 and 1983 Mental Health Acts (England \& Wales), with particular reference to consent to treatment for electroconvulsive therapy', Hist. Psychiatry, 2007, 18: 217-29. See also Moacyr Alexandro Rosa, 'Pacheco e Siva and the origins of electroconvulsive therapy in Brazil', J. ECT, 2007, 23: 224-8; Paola Bertucci and Giuliano Pancaldi (eds), Electric bodies: episodes in the history of medical electricity, Bologna, CIS, University of Bologna, 2001.

${ }^{5}$ Shorter and Healy, op. cit., note 3 above, p. 3.

${ }^{6}$ Kitty Dukakis and Larry Tye, Shock: the healing power of electroconvulsive therapy, New York, Avery, 2006; Jan-Otto Ottosson and Max Fink, Ethics in electroconvulsive therapy, New York, Brunner-Routledge, 2004; Richard D Weiner, The practice of electroconvulsive therapy: recommendations for treatment, training, and privileging, 2nd ed., Washington, DC, American Psychiatric Association, 2001. 
ECT and other somatic treatments have been produced by Thomas Szasz, Peter Breggin, and other opponents of biological psychiatry. ${ }^{7}$ In addition, warnings about the use of somatic treatments have been issued by the psychiatrist and historian Joel Braslow, who has carried out one of the few thorough historical analyses of the use of ECT in American mental hospitals in the first half of the twentieth century. Braslow argues that the therapy was used not only to save lives but also for a host of purposes ranging from corporeal control to the alleviation of despair. ${ }^{8}$

The forerunners of ECT, Cardiazol shock treatment and insulin coma therapy, have also attracted the attention of historians. Yet the studies of these therapies are not as extensive as in the case of ECT. Insulin coma therapy (ICT), also known as insulin shock therapy, has received most scholarly interest, and some aspects of its history in Germany, Britain, and the United States have been explored. ${ }^{9}$ In a study of ICT in the United States, Deborah Doroshow has analysed a sample of twenty-two patient records from Hillside Hospital in Glen Oaks. ${ }^{10}$ Even though the accounts of this therapy are not as favourable as those of ECT, insulin therapy is described in rather positive terms by historians. Doroshow notes that it was "an efficacious treatment for schizophrenia within the local world in which it was administered", ${ }^{11}$ and David Healy argues that ICT

\footnotetext{
${ }^{7}$ Peter R Breggin, Brain disabling treatments in psychiatry: drugs, electroshock, and the psychopharmaceutical complex, 2nd ed., New York, Springer, 2007; Thomas Szasz, Coercion as a cure: a critical history of psychiatry, New Brunswick, Transaction Publishers, 2007, pp. 117-50. See also Robert Whitaker, Mad in America: bad science, bad medicine, and the enduring mistreatment of the mentally ill, New York, Basic Books, 2002, pp. 96-106; Phil Fennell, Treatment without consent: law, psychiatry, and the treatment of the mentally disordered people since 1845, London, Routledge, 1996, pp. 126-47. For older critical studies, see John Friedberg, Shock treatment is not good for your brain, San Francisco, Glide, 1976; Leonard Roy Frank (ed.), The history of shock treatment, San Francisco, L R Frank, 1978; Peter Roger Breggin, Electroshock: its brain-disabling effects, New York, Springer, 1979.

${ }^{8}$ Joel Braslow, Mental ills and bodily cures: psychiatric treatment in the first half of the twentieth century, Berkeley, University of California Press, 1997, pp. 95-124. This is, in fact, the only study of ECT where patient records are used in the analysis. Braslow has analysed fifty-nine records of ECT patients from Stockton State Hospital. Braslow's book also contains studies of malaria fever therapy and lobotomy. For other studies of these somatic treatments, see Magda Whitrow, Julius Wagner-Jauregg (1857-1940), London, Smith-Gordon, 1993; Edward M Brown, 'Why Wagner-Jauregg won the Nobel Prize for discovering malaria therapy for general paresis of the insane', Hist. Psychiatry, 2000, 9: 371-82; Lucy Jane King,
}

\author{
'The best possible means of benefiting the incurable: \\ Walter Bruetsch and the malaria treatment of paresis', \\ Ann. Clin. Psychiatry, 2000, 12: 197-203; Elliot S \\ Valenstein, Great and desperate cures: the rise and \\ decline of psychosurgery and other radical treatments \\ for mental illness, New York, Basic Books, 1986; Jack \\ D Pressman, Last resort: psychosurgery and the limits \\ of medicine, New York, Cambridge University Press, \\ 1998; Marietta Meir, “'Soziale Heilung” als Ziel \\ psychochirurgischer Eingriffe. Leukotomie im \\ Spannungsfeld von Individuum, Anstalt und \\ Gesellschaft', Schweizerische Zeitschrift für \\ Geschichte, 2004, 54: 410-25; Kenneth Ögren and \\ Mikael Sandlund, 'Psychosurgery in Sweden \\ 1944-1964', J. Hist. Neurosci., 2005, 14: 353-67; \\ Mical Raz, 'Between the ego and the icepick: \\ psychosurgery, psychoanalysis, and psychiatric \\ discourse', Bull. Hist. Med., 2008, 82: \\ 387-420; Zbigniew Kotowicz, 'Psychosurgery \\ in Italy, 1936-39', Hist. Psychiatry, 2008, 19: \\ 476-89. \\ ${ }^{9}$ Therese Walther, Die Insulin-Koma-Behandlung. \\ Erfindung und Einführung des ersten modernen \\ psychiatrischen Schockverfarhrens in Deutschland, \\ Berlin, Lehmann, 2004; F E James, 'Insulin treatment \\ in psychiatry', Hist. Psychiatry, 1992, 3: 221-35; \\ Max Fink, 'A beautiful mind and insulin coma: social \\ constraints on psychiatric diagnosis and treatment', \\ Harv. Rev. Psychiatry, 2004, 11: 284-90; Deborah \\ Blythe Doroshow, 'Performing a cure for \\ schizophrenia: insulin coma therapy on the wards', \\ J. Hist. Med. Allied Sci., 2007, 62 (2): 213-43. \\ ${ }^{10}$ Doroshow, op. cit., note 9 above, p. 223. \\ ${ }^{11}$ Ibid., p. 243.
}


"worked" and had "neurological effects" as well as psychological benefits for the treated patients. ${ }^{12}$

Only a few studies on the history of Cardiazol shock therapy have been conducted. Some biographical articles on the life and work of the inventor of the therapy, Lászlo Meduna, have been published. ${ }^{13}$ These have emphasized the importance of Meduna's treatment, which contributed much to the development of ECT. Apart from the biographical accounts, only a single broad study on the history of Cardiazol shock treatment in the UK has been carried out by Niall McCrae. ${ }^{14}$ Yet McCrae's account is based solely on secondary sources, with no reference to case notes and other primary sources.

This article will argue that the peer review literature of the 1930s and 1940s does not give a full insight into questions of how well shock treatments actually worked. Indeed, the history of the therapies shows that one should be cautious about using literature of the early twentieth century as evidence of efficacy. In reports by the pioneers of shock treatment unfavourable results were often ignored and stories of patients' remissions improved. As noted by Gerald N Grob, claims of therapeutic efficacy also reflected individual opinions of psychiatrists rather than conclusions drawn from a systematic body of data. ${ }^{15}$ Furthermore, in promoting the new somatic treatments, psychiatrists were fully aware of the advantages of disseminating a positive image of the new shock therapies to the public.

In Denmark shock therapy also played an important role for psychiatrists trying to enhance the status of psychiatry and increase the funding for mental hospitals. Nevertheless, they did not only appreciate shock therapy for its public relation potential alone, they also had high hopes concerning its therapeutic effect. Yet I shall claim that these expectations were

\footnotetext{
${ }^{12}$ David Healy, The creation of psychopharmacology, Cambridge, MA, Harvard University Press, 2002: "It worked in the sense that it had neurological effects. It worked in terms of generating enthusiasm in the staff. And it probably also worked for some 'psychotic' conditions by providing some relief of anxiety and some opening and mobilization of personal resources" (p. 55). As evidence of a positive effect of ICT, historians have referred to Max Fink's randomly controlled trial of insulin treatment and chlorpromazine published in 1958. Max Fink, Robert Shaw, George E Gross, and Frederick S Coleman, 'Comparative study of chlorpromazine and insulin coma therapy in psychosis', J. Am. Med. Assoc., 1958, 166 (15): 1846-50. For example, Doroshow, op. cit., note 9 above, p. 217. Yet Fink's study was rather small with only twenty-six patients in each set. In the 1950s, the effect of insulin treatment was questioned by Harold Bourne, 'The insulin myth', Lancet, 1953, ii: 964-8; Brian Ackner, Arthur Harris and A J Oldham, 'Insulin treatment of schizophrenia', Lancet, 1957, i: 607-11; Brian Ackner and A J Oldham, 'The insulin treatment of schizophrenia. A three-year follow up of a controlled study', Lancet, 1962, i: 504-6. See also Kingsley Jones, 'Insulin coma therapy in schizophrenia', J. R. Soc. Med., 2000, 93: 147-9.

${ }^{13}$ Valenstein, op. cit., note 8 above, pp. 48-50; Max Fink, 'Meduna and the origins of convulsive
}

therapy', Am. J. Psychiatry, 1984, 141 (9): 1034-41; idem, 'Induced seizures as psychiatric therapy. Ladislas Meduna's contribution in modern neuroscience', J. ECT, 2004, 20: 133-6; idem, 'Once upon a time in Hungary-The story of László Meduna', Neuropsychopharmacologia Hungarica, 2006, 8: 75-80. See also Shorter and Healy, op. cit., note 3 above, pp. 21-30, 60-6. Two new interesting articles have been published by a team of Hungarian psychiatrists: Gabór Gazdag, Brigitta Baran, Miklós Kárpáti and Zoltán Nagy, 'The history of Lipótmezö, the site of the first convulsive therapy', J. ECT, 2007, 23: 221-3; Brigitta Baran, István Bitter, Gabor S Ungvari, Zoltán Nagy and Gábor Gazdag, 'The beginnings of modern psychiatric treatment in Europe. Lessons from an early account of convulsive therapy', Eur. Arch. Psychiatry Clin. Neurosci., published online: 27 May 2008, http://www.springerlink.com/content/ 10573117661mg540/. The Hungarian studies reveal that Meduna's often cited account of the outcome of the first shock treatment is incorrect. About this, see the following pages in this article.

${ }^{14}$ Niall McCrae, "“A violent thunderstorm": Cardiazol treatment in British mental hospitals', Hist. Psychiatry, 2006, 17: 67-90.

${ }^{15}$ Gerald N Grob, The mad among us: a history of the care of America's mentally ill, New York, Free Press, 1994, p. 184. 


\section{Jesper Vaczy Kragh}

not quite fulfilled. The doctors at mental hospitals soon realized that the therapies did not cure their primary target group—schizophrenics, who occupied the majority of beds. Better results, however, were obtained with other groups of patients. Psychiatrists undoubtedly felt that with shock therapy they could do something for some of their patients, and in light of the often hopeless conditions in Danish mental hospitals in this period even small benefits were of value. Shock therapy was also useful for other purposes. The new treatment could reduce noxious symptoms like aggression, disturbance, and agitation; and, moreover, it could be employed to control unruly patients. In what follows, I will thus present a more complex picture of the use of shock therapy, in which control and notions of effective treatment were entangled with economic and professional interests.

\section{The Danish Case}

This article will focus on the least explored of the somatic treatments-Cardiazol shock therapy - and its use in Danish psychiatry will be examined for the period 1937-50. The study will concentrate on the use of the treatment in the state mental hospitals.

Between 1937 and 1950, a total of seven state mental hospitals were managed by a directorate within the Danish Ministry of the Interior. Providing between 7,000 and 7,500 beds, these institutions contained the largest number of psychiatric patients in Denmark. Apart from the state mental hospitals, a municipal mental hospital (Sct. Hans), as well as four psychiatric clinics, were situated in the capital, Copenhagen. Altogether, they had beds for about 3,000 patients. The private psychiatric sector of the Danish mental health system remained small, and consisted of only one private mental hospital (Filadelfia) with just under 200 beds. In 1940, the private, municipal and state institutions were supposed to address the needs of a population of $3,832,300 .^{16}$

In my study of Cardiazol shock treatment, I have examined patient records of three state mental hospitals, ${ }^{17}$ analysing in detail those of the hospital in Vordingborg, southern Zealand. An average establishment, it had approximately 850 beds in the late 1930s (making it the fourth largest of Denmark's seven state mental institutions) and a standard staff of eight psychiatrists. In addition, the inmates were a mixed group, composed of patients from all social strata of Danish society. ${ }^{18}$ In my study, a sample of 250 patient records will be analysed in order to examine the psychiatric practice and discourse concerning Cardiazol shock treatment. The records have been randomly sampled from different years of admission between 1937 and 1947.

Yet, as noted in other studies of patient records, case notes do not give privileged access to "what really happened", and they only partly and incompletely describe what was said and

\footnotetext{
${ }^{16}$ In 1937 , a total of 9,985 beds for psychiatric patients existed, 6,940 in the state hospitals; in 1950, 10,638 beds, 7,445 in the state hospitals. Medicinalberetning for Kongeriget Danmark $i$ året 1937, Copenhagen, Hagegrup, 1940, pp. 138-9; Medicinalberetning for Kongeriget Danmark $i$ året 1950, Copenhagen, Hagegrup, 1952, pp. 124-5. On Danish psychiatry, see Jesper Vaczy Kragh (ed.), Psykiatriens historie i Danmark, Copenhagen, Hans Reitzels Forlag, 2008; Jette Møllerhøj, 'On unsafe ground: the practices and institutionalization of
}

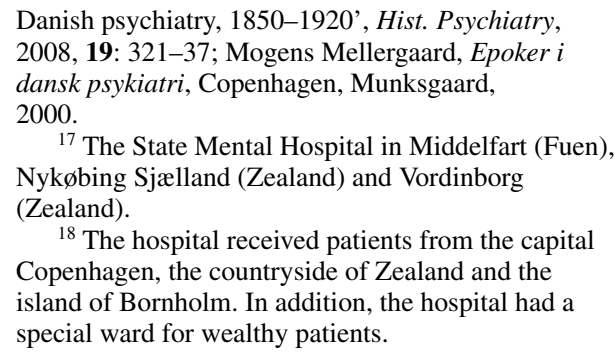

${ }^{17}$ The State Mental Hospital in Middelfart (Fuen), Nykøbing Sjælland (Zealand) and Vordinborg (Zealand).

18 The hospital received patients from the capital Copenhagen, the countryside of Zealand and the island of Bornholm. In addition, the hospital had a special ward for wealthy patients. 


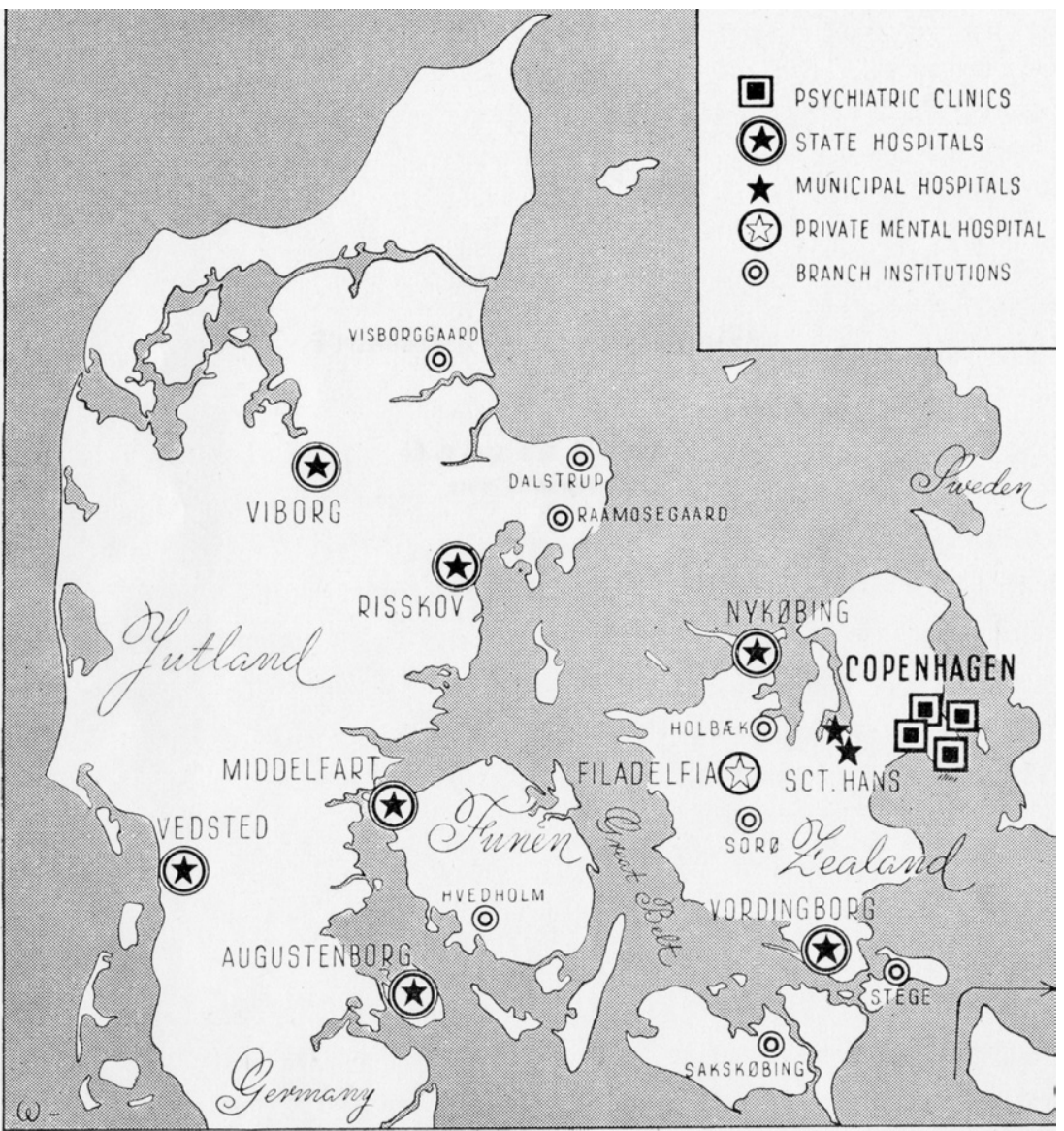

Figure 1: Map of Denmark showing psychiatric institutions in 1952. The branch institutions were placed under the control of the state mental hospitals. These institutions were intended for elderly psychiatric patients. (Courtesy of Medical Museion, University of Copenhagen.)

done. ${ }^{19}$ Like all historical sources, medical records must be evaluated carefully and, furthermore, compared to other available sources. In order to acquire a broader view of the psychiatrists' considerations regarding somatic treatment, I will, therefore, examine other kinds of information from diaries, letters, government archives, annual reports and hospital files.

${ }^{19}$ Braslow, op. cit., note 8 above, p. 8 . The use of patient records as a source for historians is usually dated back to the article by Erwin Ackerknecht, "A plea for a "behaviourist" approach in writing the history of medicine', J. Hist. Med. Allied. Sci., 1967, 22: 211-14. Since then, a substantial literature on medical history and patient records has been produced: Guenter B Risse and John Harley Warner, 'Reconstructing clinical activities: patient records in medical history', Soc. Hist. Med., 1992,
5: 183-205; Steven Noll, 'Patient records as historical stories: the case of Caswell Training School', Bull. Hist. Med., 1994, 68: 411-28; Jonathan Edwards, 'Case notes, case histories, and the patient's experience of insanity at Gartnavel Royal Asylum, Glasgow, in the nineteenth century', Soc. Hist. Med., 1998, 11: 255-81; Jonathan Gillis, 'The history of the patient history since 1850 ', Bull. Hist. Med., 2006, 80: 490-512. 


\section{Jesper Vaczy Kragh}

This article is not, however, intended to be an all-inclusive study of Cardiazol shock therapy in Danish psychiatry. Rather, my primary aim is to provide a better understanding and knowledge of issues not mentioned in the contemporary peer review literature on this therapy.

\section{The Cardiazol Myth}

Cardiazol shock therapy was invented by the Hungarian psychiatrist László Meduna (1896-1964) in 1934. He originally trained as a neuropathologist, but had begun working as a psychiatrist in Budapest in the late 1920s. Meduna's discovery of the new treatment was based on a specific theory. He had noticed that epilepsy appeared uncommon in populations of schizophrenics, and he had begun to search for evidence as to why this should be. After studying the brains of epileptic and schizophrenic patients, he claimed to have observed subtle differences in glial cells between the two groups. Consequently, he suggested the existence of a "biological antagonism between epilepsy and schizophrenia" and, moreover, that convulsions might have a beneficial effect on schizophrenic patients. ${ }^{20}$ In November 1933, he conducted a series of tests on animals in order to find a suitable substance for inducing convulsions, and he finally came across camphor. At the beginning of 1934, he was ready to try camphor on the first patient at the state asylum in Budapest-Lipotmezö. Later on he switched to Cardiazol (pentylenetetrazol), a drug originally used for patients with heart problems. Cardiazol (Metrazol in the USA) could also induce convulsions and had the advantage that it worked more rapidly and effectively than camphor. In 1935, Meduna published the results of what he termed "the first" twenty-six treated patients, reporting recovery in ten patients and improvements in three. ${ }^{21}$

Meduna's initial experiments have been subject to many myths and stories of life reborn. As in the most recent book on shock therapy by Shorter and Healy, the standard narrative begins with the treatment of the first patient and ends with a remarkable recovery. ${ }^{22}$ According to this account, the first patient was a 33-year old man, who was admitted to the hospital in Budapest with symptoms of catatonia (in this case stupor). On 23 January 1934, Meduna gave him the first injection of camphor-in-oil, and the patient had "a classical epileptic attack that lasted sixty seconds". Over the next two weeks, the patient had four more injections, and he subsequently began to respond to the treatment:

for the first time in four years he got out of his bed, began to talk, requested breakfast, dressed himself without any help, was interested in everything around him, asked about his disease, which he recognized, and asked how long he had been in hospital. When the staff told him "four years," he was unable to believe it. ${ }^{23}$

\footnotetext{
${ }^{20}$ Ladislaus von Meduna, Die Konvulsionstherapie der Schizophrenie, Halle, Carl Marhold, 1937, p. 7. "Zwischen der Epilepsie und der Schizophrenie besteht ein biologischer Antagonismus." As noted by Berrios, op. cit., note 1 above, p. 108, the idea of an antagonism has not been supported by later research. All translations from German and Danish are by the author.

${ }^{21}$ Ladislaus von Meduna, 'Versuche über die biologische Beeinflussung des Ablaufes der Schizophrenie: Campher- und Cardiazolkrämpfe', Zeitschrift für die gesamte Neurologie und Psychiatrie, 1935, 152: 235-62.
}

\footnotetext{
${ }^{22}$ For other examples, see Richard Adams, 'The treatment that will not die: electroconvulsive therapy', Psychiatr. Clin. N. Am., 1994, 17: 525-30, pp. 526-7; Max Fink, 'Convulsive therapy: a review of the first 55 years', J. Affec. Disord., 2000, 63: 1-15, pp. 1-3; Edward Shorter, A history of psychiatry: from the era of the asylum to the age of Prozac, New York, John Wiley, 1997, pp. 215-16. This story is even referred to in the critical study by Whitaker, op. cit., note 7 above, p. 92. p. 27.
} 


\section{Shock Therapy in Danish Psychiatry}

After some relapses and new treatments, the patient "felt so good that he escaped from the institution", and went home where he found his wife in bed with a lover. He beat up the lover and "kicked him out of the house, declaring that he preferred to live in a mental hospital than in this crazy world. From then on Meduna considered the patient cured, and in fact he remained well at the time Meduna emigrated from Hungary in 1939". ${ }^{24}$

This story of success, however, is based on Meduna's autobiography written about twenty years after the first treatment. ${ }^{25}$ Studies of the medical records of Meduna's hospital reveal that the oft-repeated account is incorrect in more ways than one. ${ }^{26}$ First of all, the 33 -year-old man, Zoltán L, was not the first patient to receive shock treatment: nine other patients had been treated before him. The first attempt to induce a seizure was recorded on 2 January 1934 when Meduna injected camphor into six patients. ${ }^{27}$ Secondly, it can not be verified that Zoltán L escaped from the hospital and beat up the lover: there is no mention of this episode in the patient record. ${ }^{28}$ Thirdly, Zoltán L was not cured or discharged and relapsed some time after each treatment. According to his patient record, he received a total of thirty-six sessions of camphor and Cardiazol shock therapy in 1934-35, but after this period the treatments did not have any therapeutic effect. His condition did not improve in the following years and he died in the hospital in $1945 .^{29}$

As Jack D Pressman reminds us in his study of the history of lobotomy, tales of medical innovation are often made up in order to give an impression of science advancing logically and progressively. ${ }^{30}$ This applies not only to lobotomy and Cardiazol therapy, but also to electroshock. As Shorter and Healy have demonstrated, the narrative of the first electroshock treatment by its Italian inventors, Ugo Cerletti and Lucio Bini, was far from flawless. Cerletti and Bini were so eager to give the public a perfect story of successful treatment that they concealed a few weaknesses and claimed that the first patient had been rescued from a debilitating illness. Later on, they covered up the fact that the first patient was not cured and got re-admitted. ${ }^{31}$ Insulin coma therapy is no exception to this kind of historical fiction, and Manfred Sakel also improved his story of ICT. ${ }^{32}$

In the first half of the twentieth century these tales were not questioned. The press usually supported stories of potent treatments, and often hailed shock therapy and lobotomy as great successes. ${ }^{33}$ As Andrew Scull notes, historians of medicine followed a similar line and took up "the most readily available materials, the theoretical pronouncements

\footnotetext{
${ }^{24}$ Ibid., pp. 26-8.

${ }^{25}$ Meduna's autobiography is in the Meduna Papers at the University of Illinois Archives. A condensed version in English was published by Max Fink, 'Autobiography of L. J. Meduna', Convulsive Ther., 1985, 1: 43-57, and 121-35.

${ }^{26}$ Baran, et al., op. cit., note 13 above.

${ }^{27}$ Gábor Gazdag, István Bitter, Gábor S Ungvari, Brigitta Baron and Max Fink, 'László Meduna's pilot studies with camphor inductions of seizures: the first 11 patients', J. ECT, 2009, 25: 3-11.

${ }^{28}$ Personal communication, Gábor Gazdag, 2 July 2008.

${ }^{29}$ Baran, et al., op. cit., note 13 above; Gazdag, et al., op. cit., note 27 above. Gazdag has found other discrepancies in Meduna's reports. Four of the first-treated patients were not included in Meduna's
}

1935 article. In their study of the case notes of the first eleven patients, Gazdag and his co-workers conclude that only three of these patients improved with the treatment.

${ }^{30}$ Pressman, op. cit., note 8 above, pp. 96-101.

${ }^{31}$ Shorter and Healy, op. cit., note 3 above, p. 43.

${ }^{32}$ Valenstein, op. cit., note 8 above, pp. 53-4, and Shorter and Healy, op. cit., note 3 above, pp. 11-21. See also Edward Shorter, 'Sakel versus Meduna: different strokes, different styles of scientific discovery' J. ECT, 2009, 25: 12-14.

${ }^{33}$ Gretchen J Diefenbach, Donald Diefenbach, Alan Baumeister and Mark West, 'Portrayal of lobotomy in popular press: 1935-1960', J. Hist. Neurosci., 1999, 8: 60-9; Hirshbein and Sarvananda, op. cit., note 4 , above. 


\section{Jesper Vaczy Kragh}

in the published professional literature of their day, to construct a portrait of progressive therapeutic enlightenment and progress". ${ }^{34}$ It has only been in the last decades that historians of psychiatry, inspired by the work of Charles Rosenberg and John Harley Warner in other fields of medicine, have become aware of the need for more research on somatic treatments and the importance of using patient records and other primary sources in studying these therapies. ${ }^{35}$ The new historical studies of the early reports of the founders of somatic treatments in psychiatry show the relevance of this approach and that these tales of medical innovation should be studied with caution.

\section{"It's like a Miracle!"}

In 1935, however, Meduna's report was taken at face value, and within a year interest in the therapy had spread widely to many countries, partly stimulated by Meduna's extensive travels throughout Europe and the United States. ${ }^{36}$ Thus, when Aubrey Lewis of the Maudsley Hospital in London made his famous investigation of European psychiatry for the Rockefeller Foundation in 1937, he noted that many psychiatrists had begun using Meduna's therapy. In Denmark, Lewis visited the Psychiatric Clinic at Rigshospitalet (Copenhagen), and he observed that the chief physician, Georg Stürup, "had already been working a little with Cardiazol" and was arranging to go to Switzerland "so that he might introduce into the clinic insulin treatment". ${ }^{37}$

In November 1937, psychiatrists at Rigshospitalet had been the first to use Cardiazol shock therapy in Denmark. The second hospital to follow suit was the mental hospital in Vordingborg.

At Vordingborg, Cardiazol shock treatment was usually started between 7 and 10 a.m. The selected patient would be placed on his or her back in bed with arms and legs stretched out. A pillow was placed under the patient's head and a folded pillow put under the shoulders to prevent injuries due to forceful seizures. The patient would then receive an intravenous injection of Cardiazol, usually about 50 to 70 centigrams of a 10 per cent aqueous solution. About ten seconds after the Cardiazol injection, the doctor in charge of the treatment would grab the patient's wrists and in the same movement press the patient's shoulders down. In the following 50 seconds, in which the convulsions generally lasted, the patient had tonic seizures with stiffening of the body and subsequently clonic seizures. The skin of the patient turned blue, arms and legs jerking rapidly and rhythmically until the patient eventually passed out.

The hospital's staff doctor, Victor Hahnemann, kept records of the treatments, and a special chart was made for each patient, registering the dose of Cardiazol, the latency time from the injection to onset of the convulsions, and the duration of the seizures. In 1939,

\footnotetext{
${ }^{34}$ Andrew Scull, 'Somatic treatments and the historiography of psychiatry', Hist. Psychiatry, 1994, 5: $1-12$, p. 2.

${ }^{35}$ Charles Rosenberg, 'The therapeutic revolution: medicine, meaning, and social change in nineteenth-century America', Perspect. Biol. Med., 1977, 20: 485-506; John Harley Warner, The therapeutic perspective: medical practice, knowledge, and identity in America, 1820-1885,
}

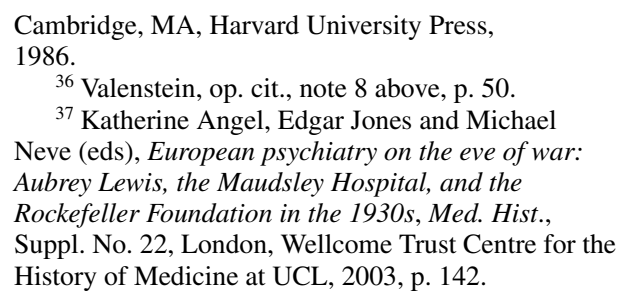




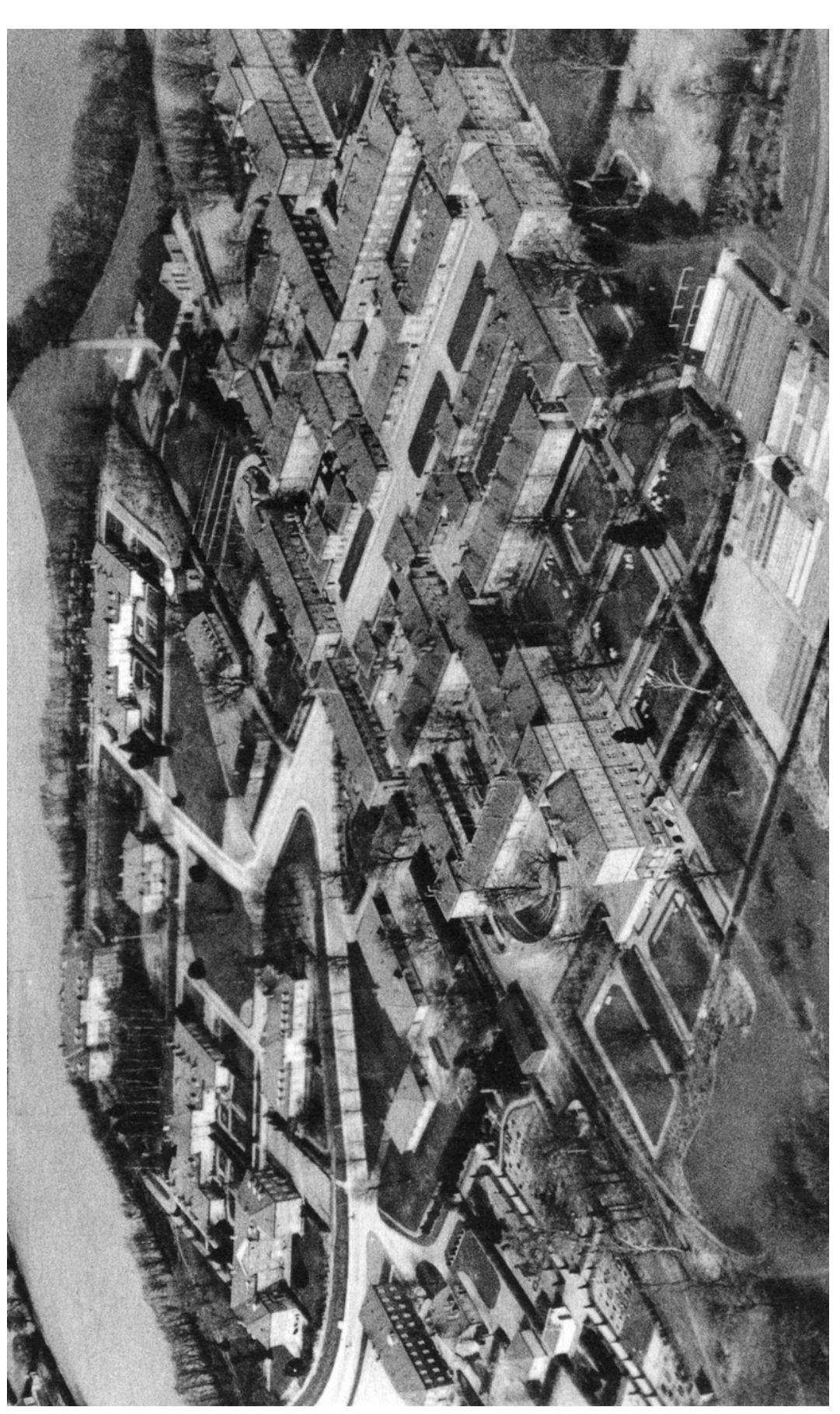

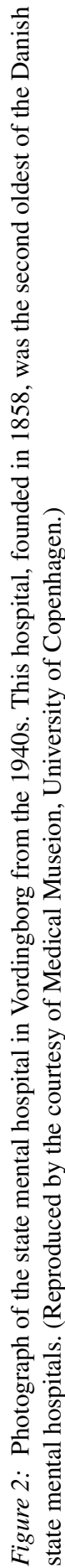




\section{Jesper Vaczy Kragh}

Hahnemann examined the results of the treated patients, and he claimed to have obtained just as positive an outcome as Meduna. Of 207 schizophrenic patients, 19 per cent had "full remission" and were thus free of all symptoms and could resume work, 33 per cent had "improved" and had only small symptoms and were more self-reliant, and finally 48 per cent were "unchanged". In addition, Hahnemann had treated 39 patients with mood disorders ("depression" and "mania") and all obtained full remission. Consequently, he concluded that psychiatry had "a valuable remedy in the treatment not only of schizophrenia but also of mood disorders". 38

Besides Cardiazol shock therapy, other treatments raised the hopes of Danish psychiatrists. In the 1930s, they had become aware of insulin coma therapy, invented by Manfred Sakel in Vienna. In the monograph Neue Behandlungsmethode der Schizophrenie (1935), Sakel described a new cure for schizophrenic patients. By giving massive doses of insulin, he had induced a state of hypoglycaemic coma in his patients with schizophrenia. After remaining for some time in death-like comas, the patients would be brought back to consciousness with a sugar solution. Sakel assumed that this process had a beneficial effect on schizophrenic patients, and in his monograph he stated that 70 per cent of the patients had "full remission". 39

In November 1936, insulin coma therapy was introduced in Denmark. This year, Otto Jul Nielsen, staff doctor of the psychiatric department of Frederiksberg Hospital (Copenhagen), had visited Sakel's clinic in Vienna. ${ }^{40}$ When Nielsen returned to Denmark in November, he began to do experiments with ICT. The state mental hospital in Risskov (Jutland) introduced the treatment in spring 1937, and the other state hospitals commenced ICT shortly after. ${ }^{41}$

ICT and Cardiazol shock therapy were both received with great optimism in the late 1930s. In December 1938, Hans Jacob Schou, chief physician at the mental hospital in Dianalund (Zealand), commented on the new treatments in his diary:

Psychiatric therapy has made such great progress that for the first time we have obtained effective treatments, that is, shock treatment with insulin and Cardiazol. Even though we do not know if the results will last, it is yet so surprising and gratifying that we can produce a complete, positive change in psychoses that it gives a whole new perspective to our work. Previously we could only register and treat symptomatically, but we can go now directly to the aetiology of the disease and are able to cure it. It's like a miracle! ${ }^{42}$

\footnotetext{
${ }^{38}$ Victor Hahnemann, 'Kliniske Erfaringer

efter 1 Aars Behandling af Psykoser med

S. K. Cardiazolchok', Ugeskrift for Lager,

1939, 101: 771-9, p. 779: "et værdifuldt Middel

til Behandling ikke blot af Skizofreni, men

ogsaa af Stemningspsykoserne".

${ }^{39}$ Manfred Sakel, Neue Behandlungsmethode der Schizophrenie, Vienna, Moritz Perles, 1935, p. 111. See also, Doroshow, op. cit., note 9 above, pp. 2-3; James, op. cit., note 9 above, p. 221.

${ }^{40}$ Otto Jul Nielsen, 'Hypoglykæmien i Neurologien og Psykiatrien', Hospitalstidende, 1937, 80: $47-53$.

${ }^{41}$ Otto Jul Nielsen, 'Insulin- og Cardiazolbehandlingen ved Schizofreni', Ugeskrift for Lager, 1938, 109: 80-5; Gudmund Magnussen,
}

\begin{abstract}
'Om Insulinbehandlingen, dens Grundlag og fysiologiske Virkemaade', Ugeskrift for Lager, 1939, 110: $1467-75$.

${ }^{42}$ Kolonien Filadelfias, Dianalund, Museum og Arkiv (Museum and Archive of the Hospital Kolonien Filadelfia in Dianalund), 'H. I. Schous dagbog 1921-1946', 31 Dec. 1938: "Sindssygebehandlingen har gjort det store Fremskridt, at vi for første Gang har faaet en effektiv Behandling nemlig Chokbehandling med Insulin og Cardiazol. Selvom vi ikke kender de blivende Resultater, er dog dette, at vi kan fremkalde et totalt Omslag i Psykosen i gunstig Retning noget saa overraskende og glædeligt, at det giver et helt nyt Perspektiv på vor Gerning. Hvor vi før kun registrerede og behandlede symptomatisk, er det nu, som om vi rammer Ætiologien og kan kurere. Det er som et Mirakel!”
\end{abstract}




\section{Shock Therapy in Danish Psychiatry}

In the late 1930s, the issue of shock treatment was debated at meetings attended by large groups of psychiatrists. In September 1937, Cardiazol and insulin therapy were discussed for the first time at a meeting of the Danish Psychiatric Society (Dansk Psykiatrisk Selskab), of which almost all Danish psychiatrists were members. ${ }^{43}$ This first meeting raised interest in shock therapy, and at another meeting of the Society about six months later several psychiatrists reported on their own experiments. In the middle of 1938, Cardiazol shock therapy and ICT had spread to all Danish mental hospitals and clinics. ${ }^{44}$ As in the reports by Victor Hahnemann, ICT and Cardiazol shock therapy were described in positive terms by Danish psychiatrists in the late 1930s. The literature focused on case stories describing the beneficial effect of these therapies, reporting positive outcomes in up to 50 per cent of patients treated. ${ }^{45}$

\section{Cardiazol and Control}

However, the patient records of the mental hospital in Vordingborg reveal that there was another side to Cardiazol shock therapy. In March 1939, a 39-year-old male patient diagnosed with manic depression wrote to his family about the new treatment in a letter that was confiscated by the psychiatrists:

Lately I have had 5-7 injections with something called Cardiazol. It is injected in a vein in the right elbow joint. It is something new Dr Hahnemann says. It has a very strong effect, completely different from anything else I have been injected with up until now. About 10 seconds after having received the injection, it is as if you are pulled out of yourself and into another world, but you can still see the persons around you as if in a limpid fog. It is utterly unbearable and quite impossible to get out of. Sometimes the effect is stronger, sometimes weaker; when it is strong you have hallucinations ... The room you are lying in begins to look like Hell, and it is as if you are burned by an invisible fire. It is very scary. But luckily it is over now. ${ }^{46}$

It was not only the 39-year-old man who had mixed feelings about the therapy. The powerful effect of Cardiazol was feared by many patients. The psychiatrist Villars Lunn recalled that as a consequence some of the patients had to be treated against

\footnotetext{
${ }^{43}$ Villars Lunn, 'Dansk Psykiatrisk Selskab 1908-1983', Nordisk Psykiatrisk Tidsskrift, supplement 1985, 39: 7-103.

${ }^{44}$ Psykiatrisk Historisk Museum, Risskov (Psychiatric History Museum in Risskov), Dansk Psykiatrisk Selskab, Journalsager, No. 94, 'Medlemsmøder 1936-1957'.

45 'Report on the seventh congress of Scandinavian psychiatrists held in Oslo, Norway, 1938', Acta Psych. Neurol., Scand., 1938, 13. The fear patients had of Cardiazol shock therapy was not recognized in the Danish peer review literature of the late 1930s. In the 1940s, however, it was mentioned in some of the psychiatric textbooks. Erik Strömgren, Psykiatriske Behandlingsmetoder, Copenhagen, Ejnar Munksgaard, 1941, p. 10.

${ }^{46}$ Oringe Arkiv, Vordingborg (Archives of the Hospital Oringe in Vordingborg) (hereafter OAV),
}

\author{
Patientjournaler, Mænd (patient records, males), \\ No. 9,446: "I den sidste Tid har jeg faaet ca. 5-7 \\ Indsprøjtninger med noget der hedder Cardiazol. Det \\ bliver indsprøjtet i en Vene ... inden i højre Albueled. \\ Det er noget nyt siger Dr. Hahnemann. Det har en \\ meget stærk Virkning, helt forskellig fra alt Andet, \\ hvad jeg hidtil har været indsprøjtet med. Ca. 10 \\ Sekunder efter man har faaet Injektionen, bliver man \\ med ét ligesom rykket ud af sig selv ind i en anden \\ Verden, men dog ser man de omkringstaaende \\ ligesom i en vandklar Taage. Der er aldeles ulideligt \\ og fuldkommen umuligt at komme ud af. Sommetider \\ er Virkningen stærkere, sommetider svagere; \\ naar den er stærk, bliver man hallucineret (ser syner). \\ Stuen man ligger i kommer til at ligne Helvede \\ og man ligesom brændes af en usynlig Ild. Det er \\ meget uhyggeligt. Men nu er det heldigvis \\ forbi".
}


their will: "It happened that four of us had literally by force to overcome the patient's resistance - and in the following minutes to watch her agonizing fear before the seizures set in." ${ }^{47}$ Hahnemann in Vordingborg also had to struggle with some inmates, and in the records there are several comments about patients who were "extremely scared of Cardiazol treatment". For instance, a female patient was so "afraid of the possibility that she might again have shock treatment that she has been yelling loudly from early in the morning, has stripped her bed and threatened to tear out the staff doctor's hair". The main reason for the patients' fear was the unpleasant latency period between the Cardiazol injection and the convulsions. As a female patient explained, it was as if, just before the convulsions came, "fire was spreading through my entire body". Another patient felt that her "brain was trembling". A sense of being on the verge of dying was also reported by patients. ${ }^{48}$

Even though some of the patients resented Cardiazol therapy, psychiatrists in Vordingborg often calculated that the unpleasant experience of intense fear was outweighed by the benefits. The positive effect of the treatment on manic-depressive patients was especially noted. Before the introduction of shock therapy, manic patients occasionally reached a state of over-excitement followed by insomnia, psychomotor agitation and sitophobia. Some entered a state of delirium (delirium acutum or excited delirium syndrome), their temperature would rise and on occasions death followed. ${ }^{49}$ After the introduction of shock treatment, Danish doctors noted that the option of preventing these states of excitement by using shock therapy was "one of the greatest therapeutic discoveries". ${ }^{50}$ The benefits of the treatment on catatonia, postpartum psychosis and suicidal patients were also mentioned.

But therapeutic considerations were not the only factors influencing the use of the therapy. Occasionally psychiatrists utilized the patients' fear of Cardiazol treatment for the purpose of controlling their behaviour. One of these incidents occurred when an unruly female patient, who was described as "obstinate" and "rude", had been admitted to the hospital in Vordingborg. The woman, diagnosed with psychopathia, was "overwhelmingly scared of Cardiazol treatment", and the psychiatrists tried to change her behaviour by telling her that new treatments could be employed if she did not behave better. When one day she heard she would be given shock treatment, she asked to see the chief physician and persuaded him to stop the treatment this time. The next day, the woman had another talk with the physician, who required her to "promise to behave in a more controlled manner" if shock treatment were to be postponed. The woman succeeded in avoiding shock therapy but was later lobotomized. ${ }^{51}$

${ }^{47}$ Villars Lunn, Afsind: på sporet af en uvirkelighed, Copenhagen, Gyldendal, 1987, p. 107: "Det hændte, at vi, tit fire mand høj, bogstavelig talt med magt måtte nedkæmpe patientens modstand-for de efterfølgende minutter at bivåne hendes pinefulde angst, før krampeanfaldet udløstes".

${ }^{48} \mathrm{OAV}$, Patientjournaler, Kvinder (patient records, females), No. 18,834, 14,918 and 18,945: "saa angst for Muligheden for at hun igen skulle have Chok, at hun har raabt højt fra tidligt i morges, tømt Sengen og truet med at rive Haaret af Afdelingslægen".

${ }^{49}$ C Fürstner, 'Über delirium acutum', Archiv für Psychiatrie und Nervenkrankheiten, 1881, 5: 505-43.
Delirium acutum was also called Bell's mania.

S H Kraines, 'Bell's mania', Am. J. Psych., 1934,

91: 29-40. See also Dimitros Adams, Adrian Treloar,

Finbarr C Martin and Alastair J D Macdonald,

'A brief review of the history of delirium as a

mental disorder', Hist. Psychiatry, 2007, 18:

459-69.

${ }^{50}$ Erik Strömgren, Psykiatriske

Behandlingsmetoder, 2nd ed., Copenhagen, Ejnar

Munksgaard, 1944, p. 26.

${ }^{51}$ OAV, Patientjournaler, Kvinder, No. 18,834:

"overvældende Angst for Cardiazolbehandling". "love at opføre sig behersket". 


\section{Shock Therapy in Danish Psychiatry}

An almost similar strategy was used on a female patient who was suffering from "obsessive-compulsive neurosis" and was afraid of being infected through food, clothes, and by going to the toilet. The woman was frightened of Cardiazol injections and told the psychiatrists that she would "not accept shock treatment". They subsequently tried to make a pact with her: "It was agreed that after the last shock treatment she should give up her rituals at meals and that she would use toilet paper when she had been to the toilet." However, the doctors observed that the woman did not follow the new rules, and they began shock treatment again, but, as they noted, without "any progress regarding dressing, eating habits or toilet". ${ }^{52}$ Despite the woman's aversion to Cardiazol therapy, she was given a total of thirty shock treatments in the period 1941-44. Like the unruly patient with psychopathia, the woman was lobotomized in 1948.

However, a better result was achieved with a male patient. In the man's record, the doctors noted that "he was very unhappy about having shock treatment, and he was told yesterday that if he was willing to work in the hospital's workshop, he would have no more shocks. This had an effect, and yesterday and today he has been working well in the workshop." 53 Acceptance of working in the workshop was one of the ways patients could avoid shock treatment, but they could also achieve the same privilege in other ways. In the record of a female patient one of the psychiatrists wrote: "Contemplated Cardiazol therapy, but she is very scared of the treatment, asking to be spared. We give up the treatment on condition that this afternoon she will write a Christmas card to her parents." 54

The use of Cardiazol therapy as a way of controlling the patients' behaviour was not mentioned in the psychiatric peer review literature of the 1930s and 1940s. Another unstated factor was the treatment of patients diagnosed with psychopathia. In the literature, the indication for shock therapy was primarily schizophrenia and, later on, depressive states and psychogenic psychoses. ${ }^{55}$ However, in the sample of patient records of the mental hospital in Vordingborg, thirteen out of thirty-three patients with psychopathia were treated with Cardiazol. The rationale for this was ambiguous. In Danish psychiatric textbooks and articles, psychopathia was not characterized as an illness. It was seen as a deviant personality trait which was usually inherited and could not be cured. ${ }^{56}$ In most of the Vordingborg cases of patients with psychopathia, Cardiazol therapy was used to calm them down or to prevent problematic behaviour. Other incurable patients with such diagnoses as general paralysis (dementia paralytica), dementia organica and encephalitis epidemica

\footnotetext{
${ }^{52}$ OAV, Patientjournaler, Kvinder, No. 12,312:

"Man aftalte ved sidste Chok, at hun skulle opgive sin Ceremoni ved Maaltider, og at hun efter at have været paa Toilettet skulle tørre sig med Toiletpapir". "nogen som helst Fremgang hverken med paaklædning, spisning eller toilette".

${ }^{53}$ OAV, Patientjournaler, Mænd, No. 11,609:

"han var meget ked af at have Chok, og man foreholdt ham saa i gaar, at hvis han ville arbejde på Værkstedet, skulle han ikke have flere Chok. Dette gjorde sin Virkning, og han har i gaar og i dag arbejdet flinkt på Værkstedet".
}

\footnotetext{
${ }^{54}$ OAV, Patientjournaler, Kvinder, No. 13,731: "havde i Dag påtænkt Cardiazol Chok, men hun er meget bange for Behandlingen, beder om at blive fri. Man afstaar da fra Behandlingen paa den Betingelse, at hun i Eftermiddag skriver et Julekort til sine Forældre".

${ }^{55}$ For a detailed Danish study of psychogenic psychoses, see August Wimmer, Psychogenic psychoses, Adelaide, Adelaide Academic Press, 2003.

${ }^{56}$ Jens Christian Smith, Psykiatriske Forelasninger, Copenhagen, Ejnar Munksgaard, 1939, pp. 222-5; Paul Reiter, Om Psykopather, Copenhagen, Ejnar Munksgaard, 1946, p. 143.
} 


\section{Jesper Vaczy Kragh}

(epidemic encephalitis) also received Cardiazol shocks. ${ }^{57}$ If these patients were unruly or aggressive, shock therapy could become an option. As one of the doctors noted in the record of a female patient diagnosed with dementia paralytica,"Very hot-tempered, threatening. Experimentally: Cardiazol shock., 58

In general, diagnosis in Vordingborg did not appear to be the key factor when decisions were made to give a patient Cardiazol therapy. When Vordingborg doctors began using Cardiazol therapy in December 1937 they followed Meduna's procedure and used the treatment on patients diagnosed as schizophrenic. In March 1938, they began trying Cardiazol therapy on patients with manic depression and psychogenic psychosis, and in the early 1940s the treatment was further expanded to a broad spectrum of conditions. Except for alcoholism and drug addiction, Cardiazol was used to treat almost every diagnostic category. ${ }^{59}$ Even patients with epilepsy could be singled out for shock treatment. In the sample of 250 patient records, two out of a total of three epileptic inmates had Cardiazol therapy. Even though psychiatrists in Vordingborg assumed that shock treatment was "contra-indicated" in the case of a 29-year-old woman "because of her epilepsy", they, nevertheless, gave her two Cardiazol shocks. In the record of the second epileptic patient, a 35-year-old woman, a doctor noted: "The last few days somewhat disturbed, hot-tempered, and aggressive. Shock therapy." 60

Instead of diagnosis, most case notes focused on the patients' behaviour and physical reactions during or after treatment. As in the record of a 28-year-old female schizophrenic patient, the comments by psychiatrists were often quite brief. In February 1938, the doctors noted, "8:20 a.m. the first Cardiazol injection, 50 centigrams. After 13 seconds tonic and clonic seizures, lasting 62 seconds, deep coma." The next day one of the doctors wrote, "8:02 a.m. second Cardiazol injection, 50 centigrams, after 10 seconds tonic and clonic seizures 60 seconds." The following day it was noted that the patient was "calm after Cardizol treatment. Up all day, busy knitting, yet must still be fed". Short comments about eight new injections were subsequently made by the psychiatrists. At the end of February the woman had the last two injections, and it was noted that she was "calm, can be up and about, occupied with knitting". Yet the psychiatrists observed that shortly afterwards the woman relapsed, and she became "noisy, hot-tempered, and aggressive". 61

${ }^{57}$ OAV, Patientjournaler, Kvinder, No. 14,406, $15,297,15,565$.

${ }^{58}$ OAV, Patientjournaler, Kvinder, No. 15,297. "Vredladen, truende. Forsøgsvis: Cardiazol Shock". The woman had previously had malaria fever therapy but did not obtain full remission.

${ }^{59}$ The main categories in Danish psychiatry were: schizophrenia, manic-depressive psychosis, pre-senile and senile psychosis, cerebrovascular disease, neurosyphilis, epilepsy, psychogenic psychosis, neurosis, psychopathia, mental deficiency, alcoholism, and drug addiction. In his study of ECT, Joel Braslow has pointed to a similar procedure at Stockton State Hospital. Braslow, op. cit., note 8 above, pp. 102-3.

${ }^{60} \mathrm{OAV}$, Patientjournaler, Kvinder, 28,803 and 30,152. "paa grund af hendes Epilepsi maa
Chokbehandling formentlig anses for kontraindiceret $(28,803)$. "De sidste par Dage noget urolig, vredladen og aggressiv. Chok-behandling" $(30,152)$.

${ }^{61}$ OAV, Patientjournaler, Kvinder, 8,562: "8:20 første Cardiazol Injection 50 ctgr. Efter 13 Sekunder toniske og kloniske Kramper, der varer 62 Sekunder, dyb bevidstløshed". "8:02, anden Cardiazol Injection, 50 ctgr., efter 10 Sekunder toniske og kloniske Kramper, 60 Sekunder". "Rolig siden Cardiazolkuren. Oppe hele Dagen, strikker flittigt, maa dog endnu mades". "Rolig, kan være oppe, beskæftiges med strikning". "larmende, vredladen, aggressiv". 


\section{Shock Therapy in Danish Psychiatry}

The psychiatrists at Vordingborg usually paid attention to highly visible symptoms such as aggressiveness, destructiveness, or psychomotor agitation; and often recorded the effect of Cardiazol therapy on these symptoms. Thus, in the case of a male patient, who was described as "aggressive" and "incontinent", the doctors noticed that during Cardiazol treatment he became "calm, clean, eats well, reads the newspaper". Yet three weeks later they observed that "the first fourteen days after Cardiazol therapy, the patient was well", but then he became "disturbed" again. ${ }^{62}$ In the record of another male patient, the doctors made several observations on the effect of Cardiazol therapy on the man's destructiveness. After giving him a series of nine shocks, they noted that he had become calm and was less destructive. Shock treatment was terminated but taken up again. After observing that the patient had relapsed, one of the doctors noted: "Because of an enormous urge to destroy his clothes, shock treatment." 63

\section{Cardiazol and Contentment}

"Destructive", “aggressive", “disturbed", “messy”, “obstinate”, “hot-tempered", "incontinent", and "noisy" patients, often became candidates for shock treatment. Most of these patients were placed in one of the many "disturbed wards" in Vordingborg. Cardiazol therapy, however, was not used only on inmates who posed a problem for the staff. Several patients with diagnoses such as neurosis, psychogenic psychosis and depressio mentis, and hospitalized in the wards for quiet patients, were treated in the same way. In their records there was no mention of conflicts with the staff, and psychiatrists in Vordingborg often had long talks with these patients about their disorders and treatment. In such cases it was not necessary for the psychiatrist to treat the inmates against their will, some even requested Cardiazol therapy. A male patient, diagnosed as manic-depressive, told one of the Vordingborg doctors that he was in low spirits and "had trouble gathering his thoughts", and the doctor noted that the patient "very much wants to be given Cardiazol treatments". After receiving the first treatment the man told the doctors that he was "a little better" but that he was still "a little anxious". ${ }^{64}$ Other patients, however, expressed much more gratitude. A female patient described Cardiazol therapy in very positive terms. In a letter to her family, she wrote that she was feeling better, it "helps to get injections every second day, it clears up my thoughts so well". ${ }^{65}$ A male patient found that a positive change had occurred after he had received a Cardiazol injection: "it was clear to me that something would help me to get well ... I was so happy", he explained. ${ }^{66}$ On occasions, the staff at Vordingborg also received grateful letters from patients who had been discharged. A male patient wrote to one of the doctors appreciating "the good treatment I have received at Vordingborg

\footnotetext{
${ }^{62}$ OAV, Patientjournaler, Mænd, 10,733: "rolig, renlig, spiser godt, læser Avis". "De første 14 Dage efter Cardiazolkuren havde Patienten det godt", "blev derpaa urolig".

${ }^{63} \mathrm{OAV}$, Patientjournaler, Mænd, 12,050: "Paa Grund af en kolossal Trang til iturivning af Tøjet, Chokbehandling".

${ }^{64}$ OAV, Patientjournaler, Mænd, 33,563: "kniber saa meget med at samle Tankerne". "Ønsker meget at
}

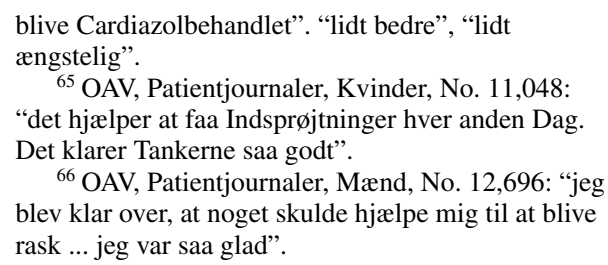


hospital", and further declared that "Cardiazol therapy" had helped him "both physically and mentally". 67

\section{The Use of Cardiazol}

Cardiazol shock therapy could thus be employed for various conditions, and psychiatrists found the treatment useful in dealing with very different types of patient behaviour. Due to the broad potential of Cardiazol therapy, the treatment was widely used in the Vordingborg mental hospital. In 1937-38, for instance, 246 patients out of a total of 1,212 had Cardiazol therapy during a period of twelve months. ${ }^{68}$ Similar figures were recorded in 1941, when 223 patients received Cardiazol therapy. Insulin coma therapy (which was very time-consuming and required more staff and surveillance than Cardiazol therapy) was used on a less regular basis. In 1941, a total of 39 patients at Vordingborg had ICT. ${ }^{69}$

Conditions at the state mental hospitals played a central role in the wide use of Cardiazol shock therapy. For decades these hospitals, including that at Vordingborg, had struggled with problems of overcrowding and a lack of psychiatrists. ${ }^{70}$ In addition, discharge rates slowed and an increasing group of patients stayed on for years. A census of patients in the state mental hospitals carried out on 1 January 1937 showed that 34.6 per cent had been institutionalized for more than ten years. ${ }^{71}$ Effective treatments that could cure these patients were not available. Before the 1930s, the tools in the therapeutic armamentarium were hydrotherapy, rest cures, work therapy and drugs such as chloral hydrate, bromides, and medinal. ${ }^{72}$ Psychotherapy and psychoanalysis were also used by some psychiatrists, yet psychoanalysis was often considered too time-consuming to be used in the state mental hospitals. ${ }^{73}$ Generally, the therapies were regarded as necessary and valuable, but psychiatrists, none the less, noted that most treatments had only a temporary, symptomatic effect. Against this background, Cardiazol shock therapy was seen as a solution for some of the problems that psychiatrists were facing in their daily clinical practise.

Schizophrenia posed a particular problem. It was usually estimated that schizophrenic patients occupied about 50 to 60 per cent of all beds in the mental hospitals. ${ }^{74}$

\footnotetext{
${ }^{67}$ OAV, Patientjournaler, Mænd, No. 14,902:

"den gode Behandling, jeg har modtaget paa

Vordingborg Hospital". "baade legemligt og sjæleligt".

${ }^{68}$ Hahnemann, op. cit., note 38 above, p. 771.

${ }^{69}$ Beretninger om Sct. Hans Hospital og Statens Sindssygehospitaler $i$ 1938, Copenhagen, Centraltrykkeriet, 1939, p. 1. Rigsarkivet (Danish State Archives) (hereafter RA). Direktoratet for Statshospitalerne (hereafter DS), Journalsager, I4, 1941/42, G 304.

${ }^{70}$ Jette Møllerhøj, 'Sindssygdom, dårevæsen og videnskab. Asyltiden 1850-1920', in Kragh (ed.), op. cit., note 16 above, pp. 88-119.

${ }^{71}$ Betcenkning afgivet af kommissionen af 29. marts 1952 vedrørende Statens sindssygevasen, Copenhagen, Centraltrykkeriet, 1956, p. 148.

${ }^{72}$ Frode Krarup and Aage Tune Jacobsen, Vejledning i Sindssygepleje, Copenhagen, H Hagerup, 1920; Alexander Friedenreich, Kortfattet, speciel
}

Psykiatri, Copenhagen, H Hagerup, 1921; Marie Anchersen, Forelasninger over Sindssygdom og Sindssygepleje, Viborg, F V Backhausen, 1924.

${ }^{73}$ Strömgren, op. cit., note 50 above, p. 13.

Futhermore, many Danish psychiatrists had reservations about Freud's work. See Finn Korsaa, 'Psykoanalysen i Danmark', Psyke og Logos, 1989, 10: 182-222; R Jensen and H Paikin, 'On psychoanalysis in Denmark', Scand. Psychoanal. Rev., 1980, 3: 103-16.

${ }^{74}$ A Wimmer, Speciel klinisk Psykiatri, Copenhagen, Ejnar Munksgaard, 1936, p. 361; Smith, op. cit., note 56 above, p. 137; Erik Strömgren, 'Status på et psykiatrisk hospital', Ugeskrift for Lager, 1955, 117: 221-5. A census of 1957 reported that 62.2 per cent of the inmates in the state hospitals had schizophrenia. K Arentsen and E Strömgren, 'Patients in Danish psychiatric hospitals: results of a census in 1957, Acta Jutlandica, 1959, 31: appendix tables 1a and $1 \mathrm{~b}$. 


\section{Shock Therapy in Danish Psychiatry}

Danish psychiatrists, who generally adhered to Emil Kraepelin's view on the subject, considered schizophrenia to be a degenerative illness with a chronic course and tragic outcome. ${ }^{75}$ Schizophrenic patients were often grouped together in the worst of the "disturbed wards", where the inmates considered to be the most aggressive, incontinent, destructive, or noisy were placed. These were large wards, sometimes with more than thirty beds. ${ }^{76}$ Various forms of physical and chemical restraints were used on a large scale in order to keep the schizophrenic patients from hurting others or themselves. In addition, the hospital staff often had serious difficulties in getting the patients to eat, take showers, and keep them dressed; and the medical records of the state hospitals reported regular fights, faeces smearing, and patients who destroyed bed linen, clothes or other things within their reach. Psychiatrists were therefore especially interested in new shock treatments for this group of troublesome, chronic patients.

However, the clinical decision of whether to use Cardiazol shock therapy was not a straightforward process, and the treatment's side effects raised ethical questions. The patients' seizures could be very severe, with joint dislocations and bone fractures as typical injuries. In particular, there were reports of vertebral fractures, and in some Danish studies these were noted in about 10 per cent of patients. ${ }^{77}$ Sometimes relatives of the treated patients complained to the Directorate of the State Mental Hospitals about the injuries. The father of a female patient notified the Directorate that his daughter had "thirteen of her teeth broken and loosened" so that they had to be pulled out, and he had observed that several other patients treated with Cardiazol had become "completely invalid" and unable to walk. ${ }^{78}$ Moreover, there were also cases of death following treatment. Patients with heart problems were especially at risk. In 1939, a 25-year-old woman was the first patient to die at Vordingborg during treatment, and similar deaths were also reported in other Danish mental hospitals. ${ }^{79}$ Patient deaths during Cardiazol therapy and ICT were reported to the Directorate of the State Mental Hospitals. The last Cardiazol death at Vordingborg occurred as late as 1951 when a 24-year-old woman died half an hour after receiving a Cardiazol injection. ${ }^{80}$ The mortality and adverse effects, however, were perceived by psychiatrists as an inevitable part of the treatments, and the complaints of relatives did not lead to a reduction in the use of the therapy or to a change in the regulations. ${ }^{81}$ In general, Danish psychiatrists

\footnotetext{
${ }^{75}$ On schizophrenia and Danish psychiatry, see Lise Østergaard, En psykologisk analyse af de formelle schizofrene tankeforstyrrelser, Copenhagen, Munksgaard, 1962. The notion of schizophrenia has also been noted by Richard Warner, Recovery from schizophrenia, 2nd ed., London, Routledge, 1994: "Scandinavian psychiatrists have tended to use a rather narrow definition of schizophrenia in an attempt to adhere to Kraepelin's emphasis on poor outcome" (p. 11).

${ }^{76}$ Beretning til Indenrigsministeren om Statens Sindssygehospitaler afgiven af Direktoren for Statens Sindssygehospitaler 1936/37, Copenhagen, Centraltrykkeriet, 1938, pp. 274-5. In this report, a 1937 survey of the state hospitals shows that 2,568 of 5,569 beds were placed in disturbed wards.

${ }^{77}$ Arild Faurbye and Ruth Poort, 'Columfraktur ved Krampebehandling af Psychoser', Ugeskrift for Lager, 1942, 104: 1019-22. Higher rates of fractures
}

of up to 40 per cent were reported in American and Dutch articles. McCrae, op. cit., note 14 above, p. 77. ${ }^{78}$ RA, DS, Journalsager, K1, 1941/42, G 304.

${ }^{79} \mathrm{H}$ Christiansen, J C Smith, G Magnussen, et. al., 'Report on insulin and Cardiazol shock therapy from the Danish Psychiatric Society', Acta Psychiatrica et Neurologica, 1942, 17: 217-97, pp. 290-3. In studies from other countries the mortality associated with Cardiazol therapy varied from 0.3 per cent to 1.6 per cent. McCrae, op. cit., note 14 above, p. 77 . ${ }^{80}$ RA, DS, Journalsager, S8, 1952/54, G 530. The hospital in Vordingborg to the Directorate, 24 Aug. 1951.

${ }^{81}$ Complaints were settled by the Directorate of the State Mental Hospitals. Only one case in 1949, a complaint about Cardiazol therapy, was taken to court, but this did not lead to regulations regarding the therapy. 


\section{Jesper Vaczy Kragh}

chose an active course regarding shock therapy, and the Directorate of the State Mental Hospitals did not question this practice.

\section{Internal Discussions}

On 14 June 1938, Cardiazol and insulin therapy were discussed for the first time at a meeting at the Directorate of the State Mental Hospitals attended by the head of the Directorate, Georg Brøchner-Mortensen, and the chief physicians of all the state mental hospitals. The physicians expressed their positive view of shock therapy, and they appealed to the Directorate for additional funds in order to optimize the treatments. Brøchner-Mortensen shared their favourable view of the new somatic treatments. Yet he was aware that psychiatrists in Sweden were more cautious than their Danish colleagues about using insulin and Cardiazol therapy. During a study tour in Sweden in 1938 he had observed that most mental hospitals had an electrocardiograph so that the patients could be examined for heart defects before Cardiazol therapy was used. At the meeting, he therefore raised the question whether all patients in Danish mental hospitals should have electrocardiography before insulin and Cardiazol therapy. ${ }^{82}$

The chief physician of the Vordingborg mental hospital, Vagn Askgaard, was the first to reply. He reported that some of his patients had electrocardiography at a nearby hospital before insulin therapy, but those who were selected for Cardiazol therapy were not "examined for heart problems". He also maintained that few patients had heart defects, and the present arrangement was the "cheapest and most practical solution for the mental hospital in Vordingborg". ${ }^{83}$ Most of the other psychiatrists at the meeting expressed similar views and followed the same procedure. Only one of the chief physicians, Valdemar Hendriksen, argued that more caution ought to be taken. He stressed that electrocardiography could reveal heart defects that otherwise would not be detected. He therefore urged that all patients be examined before insulin and Cardiazol therapy. The question of electrocardiography, however, was not resolved at the meeting, and Brøchner-Mortensen finally stated that individual psychiatrists could decide whether patients should be examined for heart defects before undergoing shock treatments.

About a year after the meeting, the Directorate requested the chief physicians to report on their use of electrocardiography. In the reports, the hospitals' expenses for the examination varied a great deal. At the mental hospital in Augustenborg, 305 patients had electrocardiography before insulin and Cardiazol therapy, whereas the Risskov hospital had used it in only five cases. Most hospitals reported that between 5 and 15 patients received electrocardiography before shock treatments. ${ }^{84}$ In 1939, the number of treated patients at the seven state hospitals varied from about 100 to more than 400 .

In order to achieve better and more even standards among the state mental hospitals, in 1939 the Directorate offered them funds to buy electrocardiograph machines. Although two hospitals rejected the offer, the rest now stressed that electrocardiography was imperative in order to avoid serious complications. Nevertheless, it took another two years before a

\footnotetext{
${ }^{82}$ RA, DS, Overlægemøder 1926-47, K4, Meeting 14 July 1938.

${ }^{83}$ Ibid. "den billigste og mest praktiske Løsning for Hospitalet i Vordingborg".
}

\footnotetext{
${ }^{84}$ RA, DS, Journalsager, I4, 1942/43, G 322, 'Udgifter til specialundersøgelser af patienter med hjertelidelser der underkastes insulin-eller Cardiazolbehandling'.
} 


\section{Shock Therapy in Danish Psychiatry}

majority of hospitals examined most patients before insulin and Cardiazol therapy. In 1941, it was decided at a meeting at the Directorate that all the state mental hospitals should have electrocardiograph machines, and examination of patients before shock treatment eventually became standard procedure. ${ }^{85}$

\section{The Shock Committee}

At another meeting in 1941, Brøchner-Mortensen informed the chief physicians that Cardiazol and insulin therapy had been received with great interest by the Danish parliament, and the Ministry of the Interior had given the first grants for the two new therapies. But Brøchner-Mortensen argued that in order to get further funding the mental hospitals had to make regular reports on the use and effect of the two therapies. After some discussion, the Directorate and the chief physicians agreed that reports were to be sent in every six months, but they would not include examinations of the effect of the treatments. ${ }^{86}$ In fact, the Danish Psychiatric Society (Dansk Psykiatrisk Selskab) was already in the process of carrying out a study on the effect of the two therapies, to which twelve psychiatric departments and mental hospitals contributed data. More than 2,000 patients were treated with either insulin or Cardiazol, and four sub-committees evaluated the results. ${ }^{87}$

In the analysis of the effect of the two treatments, five categories were used: "full remission", i.e. cure; "considerable improvement" to the extent that it was possible to discharge the patients but with lack of insight into their disease and slight remnants of other symptoms; "some form of general improvement", as a result of which, for instance, it was possible to move patients to a better ward or that patients could now occupy themselves more regularly; "temporary improvement", i.e. a remission which led to complete relapse within six weeks; and patients who were "unchanged". ${ }^{88}$ In the study of Cardiazol therapy a total of 1,675 patients were examined, of whom 782 were schizophrenic. Yet unlike some American studies, the treated cases were not compared with a corresponding control group. $^{89}$

On 25 and 26 January 1941 the results of the study were presented to the Danish Psychiatric Society. The psychiatrist Villars Lunn, who was present at these meetings, recalled the occasion and the first report by the insulin committee, who had treated 162 schizophrenic patients: "We all remember the excitement ... And then it hit us like a bomb: only four schizophrenic patients had completely recovered more than four months after the treatment had been terminated." It was "an anticlimax, an ice-cold douche", Lunn explained. ${ }^{90}$

\footnotetext{
${ }^{85}$ RA, DS, Journalsager, O8, 1943/44, G 351, Meeting 27 Jan. 1941. At the meeting, the chief physicians reported on the use of electrocardiography. Yet three of the hospitals did not examine all patients before ICT and Cardiazol therapy, testing only those who were more than forty-five years old.

${ }^{86}$ RA, DS, Journalsager, I4, 1942/43, G 322, 'Insulin' 1939/40, nr. 2a.

${ }^{87}$ Christiansen, et al., op. cit., note 79 above, p. 219.

${ }^{88}$ Ibid., p. 222.
}

\footnotetext{
${ }^{89}$ In 1938-39, Benjamin Malzberg and later Horatio M Pollock carried out large studies of Cardizol therapy and ICT using control groups. See Gerald N Grob, Mental illness and American society, 1875-1940, Princeton University Press, 1983, pp. 301-2.

${ }^{90}$ Lunn, op. cit., note 47 above, pp. 105-6: "Vi husker vist alle spændingen ... Og så sprang bomben: komplet symptomfrihed mere end fire måneder efter behandlingens afslutning var iagttaget hos fire skizofrene patienter". "Et antiklimaks, en iskold douche".
} 


\section{Jesper Vaczy Kragh}

The report on the results of Cardiazol shock therapy was no more encouraging. A total of 782 schizophrenic patients had been treated, but there were only nine full remissions. More positive results, however, had been obtained in patients with manic-depressive disorder and psychogenic psychoses. More than 40 per cent of these patients had full remissions. Consequently, the committee noted that cases of schizophrenia were only "affected to a slight degree and complete recovery has practically not been attained", but in cases of "psychogenic psychoses the results have been considerably more favourable. The favourable results obtained in these cases as well as in the manic-depressive psychoses give as little reason for the utter pessimism of some quarters as for the earlier almost unlimited optimism". 91

But at the same time, adverse effects had also been observed. One of the sub-committees had studied "the complications concerning shock therapy", and had reported that eleven deaths were attributed to the treatments. Insulin therapy had the highest risk, viz. a mortality rate of 1 per cent, while that due to Cardiazol shock was 0.5 per cent. The committee further noted that in Cardiazol shock therapy pulmonary lesions were one of the most serious complications. Additionally, cardiac complications and fractures of the vertebral column had occurred, as well as "several more disabling instances of fracture of the humerus and, especially, fracture of the neck". As a consequence, it was concluded that if the therapy was to be developed further it was necessary to reduce "the risk involved, especially with regard to pulmonary and cardiac complications, as well as fractures". 92

Yet in the years that followed, the risk was not greatly reduced. News that curare could tame seizures in convulsive therapy did not reach Denmark before the late 1940s. The Nebraska psychiatrist Abram Bennett had used curare for the first time in 1940 as premedication in shock therapy. ${ }^{93}$ In Denmark, the first experiment with curare took place in 1948, but it was only used in a few cases before ECT. ${ }^{94}$ During the 1950 s, curare or curare-like substances such as succinylcholine and anaesthesia became more common in Denmark, but by then Cardiazol shock therapy had become redundant. ${ }^{95}$

\section{Other Benefits}

After the reports of the shock committees, Danish psychiatrists recognized that ICT and Cardiazol therapy were no magic bullets in the treatment of schizophrenia. As Erik Strömgren noted in 1944, shock therapy could only "produce temporary changes" in schizophrenia, "but it can not change the course of the illness in the long run". ${ }^{96}$ Yet the disappointing results did not lead to disillusioned statements by psychiatrists in the Danish press. Rather, insulin and Cardiazol therapy were portrayed as highly successful

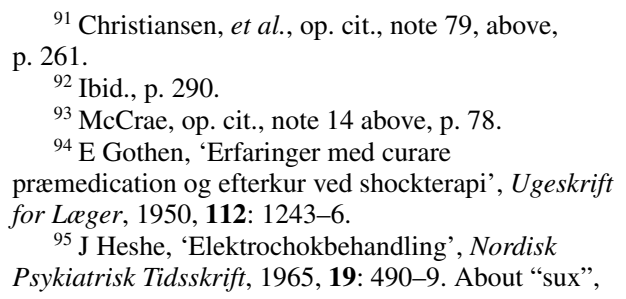

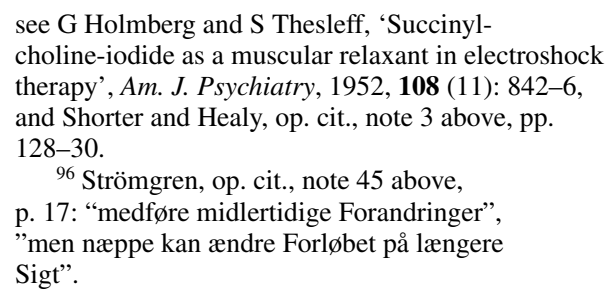

${ }^{96}$ Strömgren, op. cit., note 45 above, p. 17: "medføre midlertidige Forandringer", "men næppe kan ændre Forløbet på længere Sigt". 
treatments. In addition, lobotomy and electroshock were introduced in the early 1940s, and both these therapies were also characterized as effective. ${ }^{97}$

Despite the disappointing results of the survey on Cardiazol therapy and ICT, Danish psychiatrists mounted successful publicity campaigns depicting these treatments as a way of reforming the state mental hospitals. In a series of reports written by psychiatrists in the 1940s, these somatic treatments were often described as part of a new era in psychiatry, in which many patients would be cured. ${ }^{98}$ According to a 1947 report, use of these therapies would bring about the modernization of psychiatry. New hospitals would have to be built, and existing institutions brought up to date so that the potential of the new treatments could be fully used. In this way, "the barren custodial principles of the past will be replaced with modern treatments and make the hospitals into what they should be: real institutions of recovery". 99

In the 1940s, these campaigns had a marked influence on Danish politicians, who began to applaud the developments in psychiatry. In a parliamentary debate, the left-wing politician and neurologist, Mogens Fog, pointed out that "in the last ten years, the treatment of mental illness has undergone a thoroughgoing transformation", and it was important to support this development by building new institutions. ${ }^{100}$ Ejnar Kjær, the right-wing Minister of the Interior, shared this view. He emphasized that psychiatry had made "great progress" and mentioned as examples shock treatment and lobotomy. The existing hospitals were unable to respond "to the demands of modern treatments", and he therefore recommended that new institutions be built. ${ }^{101}$ Shortly after Kjær's statements, the government decided to build a new state mental hospital and to modernize some of the existing ones. ${ }^{102}$ Furthermore, the state hospitals received large sums specifically for the new somatic treatments. In order to improve ICT and Cardiazol therapy, funds to employ more medical doctors at all the state mental hospitals were provided in 1942; and when ECT and lobotomy were introduced later, the hospitals also received state grants to cover the expenses of the two therapies. $^{103}$

\footnotetext{
${ }^{97}$ Jesper Vaczy Kragh, 'Elektrochok, psykiatri og historie', Ugeskrift for Lager, 2005, 167: 4750-2; idem, 'Sidste udvej? Træk af psykokirurgiens historie', Dansk Medicinhistorisk Årbog, 2007, 35: 9-36. Lobotomy was introduced in Denmark in 1939, ECT in 1940. The state hospitals began using ECT in 1943.

${ }^{98}$ Betankning 1. Afgivet af Udvalget af 26. november 1943. Betimeligheden af Opforelse af nye Sindssygehospitaler i Nordjylland og paa Sjalland, Copenhagen, Centraltrykkeriet, 1944; Betankning 2 afg. af Udvalget af 26. Nov. 1943 ang. Betimeligheden af Opførelse af nye Sindssygehospitaler i Nordjylland og paa Sjalland, Copenhagen, Centraltrykkeriet, 1945.

${ }^{99}$ Betankning afgivet af Udvalget af 23. November 1945 ang. Hospitalisering af Sindssyge på Fyn og i det sydlige Jylland, Copenhagen, Centraltrykkeriet, 1948, p. 30: "erstatte fortidens golde forvaringsprincipper med moderne behandlingsmåder og omskabe
}

hospitalerne til det, de bør være: virkelige helbredelses-anstalter".

${ }^{100}$ Aalborg Stifttidende, 14 Nov. 1946:

"sindssygdommenes behandling i de sidste ti år har undergået en gennemgribende forvandling".

${ }^{101}$ Folketingets Forhandlinger, no. 3. 1946-47, p. 261: "store fremskridt", "fordringerne til de moderne behandlinger".

${ }^{102}$ RA, DS, Journalsager, D1, 1945/46, G 390, 'Forslag til lov om ombygning af Sindssygehospitalet i Viborg, Opførelse af et nyt Sindssygehospital i Brønderslev og udvidelse af Sindssygehospitalet ved Aarhus'.

${ }^{103}$ Beretninger til Indenrigsministeren om Statens Sindssygehospitaler 1942/43, Copenhagen, Centraltrykkeriet, 1943, p. 4. RA, DS, Journalsager, I4, 1943/44, G 322. Expenses for electricians and ECT machines were covered by the Ministry of the Interior as well as the cost of lobotomy operations carried out by neurosurgical departments in Copenhagen and Aarhus. 
Besides influencing journalists and politicians, psychiatrists worked on changing the attitude of the medical community in general towards psychiatry. Before the late 1930s, psychiatrists had often complained that their speciality was separated from mainstream medicine and marginalized in the medical curriculum of the universities of Copenhagen and Aarhus. ${ }^{104}$ The introduction of somatic treatments provided psychiatrists with an opportunity to raise the low status of the discipline, and with a new self-confidence they began to publish articles in Danish medical journals demanding the recognition of psychiatry as a part of medicine. "It is beyond doubt that psychiatry now is the fastest growing discipline in medicine", one of these articles stated. "Clinical psychiatry has made great progress" by using scientific methods, the article continued, and new somatic treatments such as shock therapy and lobotomy were in this respect a very "valuable contribution". ${ }^{105}$ An article in the weekly medical journal Ugeskrift for Lager by the chief physicians of all the state mental hospitals stressed that the recent development in psychiatric treatment "had made a close collaboration between psychiatry and other medical specialities necessary". It was therefore important that new mental hospitals should be situated close to regular hospitals. ${ }^{106}$

The psychiatrists' demands for recognition included a more prominent place in medical education at the universities of Copenhagen and Aarhus. In 1949, a committee of psychiatrists appointed by Dansk Psykiatrisk Selskab worked hard to change the medical curriculum of the universities. It was pointed out by the committee that the existing system, where students were not examined but only had to attend lectures in psychiatry (thirty-six in one semester) and work for one month as a medical trainee in a psychiatric department, was "obsolete". Somatic treatments and new knowledge about neurosis and mental hygiene required more training. ${ }^{107}$ Consequently, the committee proposed that three times as many lectures in psychiatry should be part of the medical curriculum and that all medical students had to pass psychiatry exams.

In 1954, most of these demands were granted. In the curriculum of the universities in Aarhus and Copenhagen a series of new courses in psychiatry were included, and a psychiatry exam established. ${ }^{108}$ The psychiatrists' objective of integrating psychiatry with medicine in other ways was also obtained. In 1952, a committee appointed by the Ministry of the Interior had evaluated the state mental hospitals and it recommended that in future

\footnotetext{
${ }^{104}$ See papers by Møllerhøj, notes 16 and 70 above.

105 Anon., 'Apropos somatisk behandling af psykiske lidelser', Ugeskrift for Lager, 1949, 111: 1001: "det er uomtvisteligt, at psykiatrien i øjeblikket er den mest ekspansive af de medicinske discipliner". "klinisk psykiatri har gjort store fremskridt". "betydningsfulde bidrag".

${ }^{106}$ Vagn Askgaard, et. al., 'Det nye sindssygehospital', Ugeskrift for Lager, 1949, 111: 1431: "har nødvendiggjort et stadigt nærmere samarbejde mellem psykiatrien og de øvrige lægevidenskabelige specialer".

${ }^{107}$ Anon., 'Betænkning vedrørende undervisningen i psykiatri ved de lægevidenskabelige fakulteter i København og Århus', Ugeskrift for Lager, 1949, 111: 789-92, p. 790. As in many other countries, neurosis was a widely discussed topic in
}

\author{
Denmark, and demands for special institutions for \\ these patients were put forward in the press and in \\ medical journals. Bjørn Hamre, 'Pulter- \\ kammerdiagnoser, rentehysteri og kristen sjælesorg', \\ in Edith Mandrup Rønn and Inger Hartby (eds), Det \\ forrykte menneske. Den psykisk syge i historien ca. \\ 1830-1980, Ebeltoft, Skipperhoved, 2006, pp. \\ 153-84. See also Petteri Pietikainen, Neurosis and \\ modernity: the age of nervousness in Sweden, Leiden, \\ Brill, 2007. On the mental health movement in \\ Denmark, see T Hansen, A Christensen, and P \\ Triantafillou, 'Da selvudvikling blev en del af den \\ psykiatriske behandlingspraksis i Danmark', Bibliotek \\ for Lager, 2006, 198: 216-42. \\ ${ }^{108}$ Årbog for Kobenhavns Universitet \\ indeholdende meddelelser for de akademiske \\ år 1953-58, Copenhagen, 1961, pp. 372-3.
}




\section{Shock Therapy in Danish Psychiatry}

such institutions should be built near general hospitals, and that the latter should also have psychiatric departments. ${ }^{109}$ In the late 1950s and 1960s these recommendations were adopted. $^{110}$

\section{Conclusion}

By the time the new plans for psychiatry were put into effect in the 1950s, Cardiazol shock therapy had been phased out. In most state hospitals it had been replaced by ECT in the late 1940s and early 1950s. ${ }^{111}$ ECT proved safer to use and, unlike Cardiazol therapy, it did not produce the same intense feelings of dread in patients. But before the late 1950s, Cardiazol shock therapy had, none the less, played a significant role in the development of Danish psychiatry. Although it was no magic bullet for schizophrenia, it did have beneficial results for other groups of patients, who would otherwise lead miserable lives in mental institutions. Furthermore, psychiatrists reported good results with patients who were suicidal, in a dangerous manic phase, or who suffered from postpartum psychosis. However, patient records of the state mental hospitals show that physicians found Cardiazol shock therapy useful for other purposes. In Vordingborg hospital the patients' fear of Cardiazol therapy was sometimes exploited in order to control their behaviour. In general, patients who were characterized as destructive, hot-tempered, noisy, and aggressive often became candidates for shock treatment. This treatment was not used exclusively on these patients, however, and inmates who posed no problem for the hospital staff were also treated with Cardiazol. In sum, Danish psychiatrists found the treatment useful in dealing with very different types of disorders, and Cardiazol therapy was used on a wide scale to treat almost every diagnostic category. Side effects of the treatment such as vertebral fractures and death were perceived as inevitable. In addition, the press did not focus on this aspect but portrayed shock therapy as highly successful. A similar view was presented by psychiatrists, for whom Cardiazol shock therapy became an important tool in efforts to enhance the status of psychiatry and increase the funding of mental hospitals. Together with other somatic treatments of the 1930s and 1940s, Cardiazol therapy was successfully employed in campaigns for grants and for recognition of the psychiatric profession in Denmark.

The resolve to change the public image of psychiatry was not only restricted to Denmark; similar efforts were made by psychiatrists in several European countries and in the United States. As Pressman notes, somatic treatments were useful to American psychiatrists, "who were waging an ideological campaign to convince the public, the general medical community, and themselves that psychiatry did indeed have medical treatments, deployable in medical settings, that functioned according to medically understandable precepts". ${ }^{112}$ Likewise, Cardiazol therapy and other somatic treatments were adopted in Germany, Switzerland, and Britain, where psychiatrists valued the therapies as a means of transforming psychiatry. ${ }^{113}$

\footnotetext{
${ }^{109}$ Betankning, op. cit., note 71 above, p. 115.

${ }^{110}$ Merete Bjerrum, 'Fra stat til amt. Dansk hospitalspsykiatri 1930-1976', in Kragh (ed.), op. cit., note 16 above, pp. 223-62.

${ }^{111}$ Cardiazol Shock therapy was still used in some hospitals in the $1950 \mathrm{~s}$, mostly on patients who refused to have or did not respond to ECT. In the
}

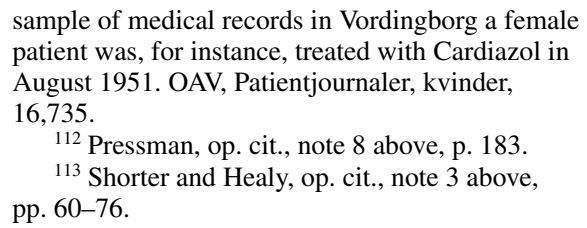




\section{Jesper Vaczy Kragh}

The Danish case, however, shows some differences when compared to that of other countries. In Denmark, Cardiazol therapy and ICT were used in every mental hospital and department, and there were no psychiatrists who opposed the wide use of these treatments. A similar spread of the two therapies cannot be found in many other countries, where Cardiazol therapy and ICT were criticized by internationally recognized psychiatrists. In Britain, for instance, Edward Mapother and Aubrey Lewis disapproved of somatic therapies; in France, Henri Baruk implored his colleagues to forsake Cardiazol shock therapy; and in Switzerland, Max Müller discarded the treatment because of the patients' agonized fears of dying. ${ }^{114}$ In the United States, Philip Polatin and co-workers reported that vertebral fractures occurred in 43 per cent of patients, and these statistics were so compelling that a number of American hospitals abandoned Cardiazol. ${ }^{115}$ In the UK, the treatment's reputation was also tarnished by published articles on the fractures it often produced, and it was discontinued in some British hospitals as a result. ${ }^{116}$ In Denmark, reports about side effects were published, but they did not affect the use of the therapy in any significant way. ${ }^{117}$

Considering these diverse responses, it is possible that the use of Cardiazol therapy in Danish mental hospitals was in some respect different from the practice in other European countries. Yet it is difficult to draw conclusions regarding this, and an in-depth comparative analysis is beyond the reach of this article. In order to get a broader picture of the general use of Cardiazol shock therapy in Europe or worldwide, more studies of medical records and other primary sources are required. So far, studies of case notes have not been common in the historiography of somatic treatments, and Cardiazol shock therapy especially is in need of further historical scrutiny.

\footnotetext{
${ }^{114}$ Edgar Jones, Shahina Rahman and Robin Woolven, 'The Maudsley Hospital: design and strategic direction, 1923-1939', Med. Hist., 2007, 51: 357-78, p. 378; Edgar Jones and Shahina Rahman, 'Framing mental illness, 1923-1939: the Maudsley Hospital and its patients', Soc. Hist. Med., 2008, 21: 107-25, pp. 120-1; Richard C Keller, 'Taking science to the colonies: psychiatric innovation in France and North Africa', in Sloan Mahone and Megan Vaughan (eds), Psychiatry and empire, London, Palgrave Macmillan, 2007, pp. 41-66, p. 28;
}

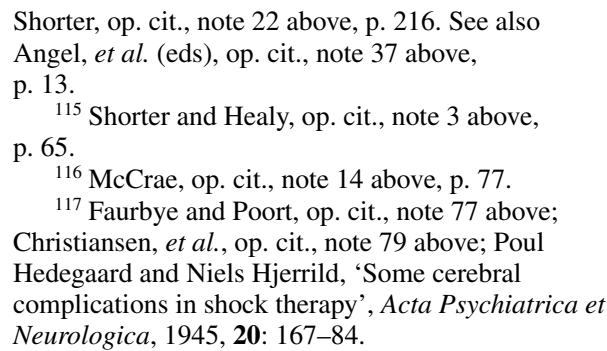

